\title{
A Content-Based Analysis of Jamshid Najafi's Azerbaijani Turkish Songs Tested Against Linguistic and Literary Themes
}

\author{
Mostafa Shahiditabar ${ }^{1}$, Mohammad Amin Mozaheb ${ }^{1} \&$ Mehdi Fatemi ${ }^{2}$ \\ ${ }^{1}$ Department of Foreign Languages, Language Center, Imam Sadiq University, Tehran, I.R. Iran \\ ${ }^{2}$ Department of Psychology, Zanjan University, Zanjan, I.R. Iran \\ Correspondence: Mohammad Amin Mozaheb, Department of Foreign Languages, Language Center, Imam Sadiq \\ University, 1465943681, Tehran, I.R. Iran. Tel: 98-8809-4001. E-mail: mozaheb.ma@gmail.com
}

Received: August 21, 2018; Accepted: September 9, 2018; Published: November 8, 2018

\begin{abstract}
Jamshid Najafi is an Iranian Azerbaijani Turkish and Farsi singer. The present study aims to analyze some of his songs in terms of literary themes. The corpus of the current study is Jamshid Najafi's Azerbaijani Turkish songs released by the permission of the Iranian Ministry of Culture and Islamic Guidance. Moreover, a content-based analysis approach is used to analyze the corpus. The analysis of the data shows that Najafi is a romantic singer whose Azerbaijani Turkish songs are replete with romantic images as well as themes. Mother is the next frequent theme found in Jamshid Najfi's works. It shows that mother has a holy position in Azerbaijani culture. Criticism of life and nostalgic themes are the next themes found in the studied corpus. Sister, child, homeland, devotee and religion are other common themes in Jamshid Najafi's songs that show the importance of these themes to his life and ideology.
\end{abstract}

Keywords: Jamshid Najafi, Azerbaijani Turkish Poems, content-based analysis

\section{Introduction}

Jamshid Najafi (Azerbaijani Turkish: Cəmşid Nacəfi) is an Iranian Azerbaijani Turkish and Farsi singer. He was born in a religious family in Iran in 1950. His mother is from Ardabil, I. R. Iran and his father is from Baku, the capital of Azerbaijan. His first practice of singing was in religious ceremonies like the commemoration of Imam Husain (a. s.). For instance, Jamshid Najafi depicted in figure 1. took part and sang in ceremonies of the Day of Ashura that is commemorated by the Shias all around the world including Iran as a day of mourning for the martyrdom of Husayn ibn Ali, the grandson of Muhammad Prophet (P. B. U. H.), at the Battle of Karbala.

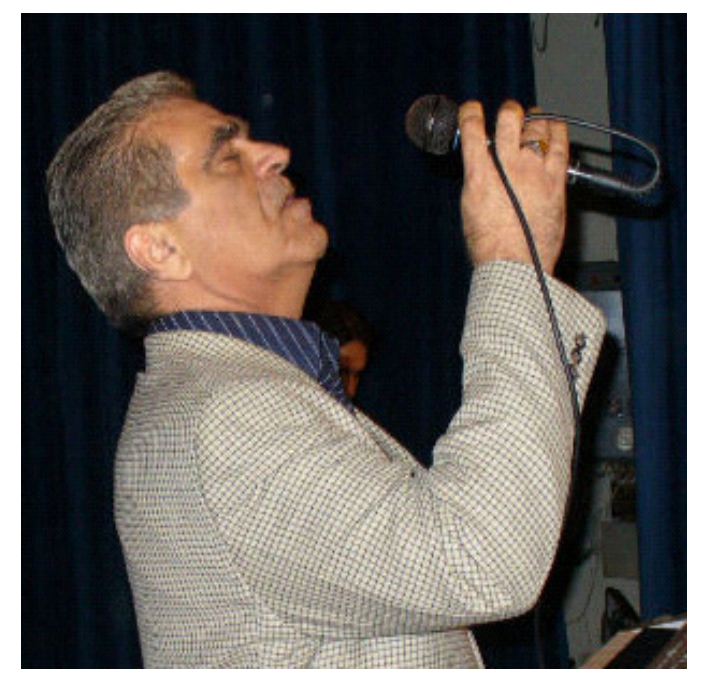

Figure 1. Jamshid Najafi performing in Ardabil, 2013

Jamshid Najafi was introduced to radio in 1972 by his friend Firooz Berenjian. His songs are in Azerbaijani Turkish and Farsi. Since he started his career as a singer, he has released many albums. His works can be divided into some 
categories. His best works relate to his songs released after 1979 and they can be seen in some classifications. Some of them are dedicated to his homeland, the Islamic Revolution of Iran or religion such as Xələbanlar (pilots), Ey Rahbar (oh Leader), Ya Mola Ali (Oh Master Ali (a. s.)), Ya Mohammad (oh Muhammad), Hamsangar (fellow traveler), Rooze Mowud (the Promised Day), Allah Akber (Allah is Great) etc.

Jamshid Najafi's well-populated works include Xələbanlar (i.e., devoted to Iranian pilots that was released in 1982 during the 8 years of imposed war between Iran and Iraq), Gecələr (i.e., Najafi's most noted and well-known song that has a romantic theme), Gəldi Baba (devoted to his daughter), among others.

\section{Significance of the Study}

Azerbaijani Turkish songs have not been studied by scholars very much on the one hand and the fact that Jamshid Najafi's works have not been considered from the viewpoint of scholars despite the fact that his works have gained considerable attention in the past decades which encouraged the authors of this study to conduct the current research.

\section{Research Question}

This study seeks to answer the following research question:

What are the main themes found in Jamshid Najafi's Azerbaijani Turkish songs?

\section{Literature Review}

A review of literature shows that despite having many studies regarding Azerbaijani Turkish poetry as Faghih (2014), Vazife (2013), Mohammadzadeh Sadigh \& Shirmohammadi (2009), Mohammadzadeh Sadigh (2006), Heyat (2006), Mirəhmadov \& Xanbabayeva (2005), Qəhrəmanov (2005), Vazife (2004) Mohammadzadeh Sadigh (2004), Rüstəmova (2002), Heyat (2001) and Heyat (1979), Azerbaijani Turkish songs have not been considered by scholars very much. It also depicts that Jamshid Najafi's works have not been studied by a large number of scholars. A few works can be seen in regard to Jamshid Najafi's songs that most of them are non-scholarly reports or reviews. Most of the works done regarding Najafi are limited to some quotations about his works that are available on websites. Some works related to Azerbaijani Turkish song/poems are as Mozaheb, M. A. and Shahiditabar, M. (2015), Mozaheb, M. A., Shahiditabar, M. and Monfared, A. and Mirzapour, F. (2016) and Shahiditabar, M., Mozaheb, M. A. and Monfared, A. (2015).

\section{Methodology}

A content-based analysis method is used to analyze the corpus which consists of the Jamshid Najafi's songs.

\section{Corpus}

This study aims to analyze Jamshid Najafi's Azerbaijani Turkish works released by a permission issued by the Iranian Ministry of Culture and Islamic Guidance. The mentioned corpus consists of 5 albums or 25 songs.

\section{Analysis}

After considering the albums of Jamshid Najafi, the main themes of his works have been obtained using a contentbased analysis approach. Then, they are shown in relevant tables and are discussed in details.

\section{Jamshid Najafi's Works}

Jamshid Najafi's Azerbaijani Turkish works are Axşamlar (evenings),Gecələr (nights), Gəldi Baba (dad came) and Neyniyim (I do not know what to do). A brief summary of themes found in the mentioned albums are given in the following.

\section{Neyniyim}

This album has six songs as Neynim (I do not know what to do), Yadigar (memorial), Həmdəm (companion), Gözal Ceyran (beautiful sweetie), Ana Mən Qəribəm (oh mother; I am alone), Ağardı Saçım (my hair went grey), Ana (mother) and $N$ a Qald $?$ ? (what has remained?).

Neynim: This song is a romantic song.

Yadigar: It is a nostalgic song that talks about the cloud in the mountain and changing of spring into fall and shows that the singer is brother-less (helpless). The singer is alone and nobody greets him.

Həmdəm: It is about the romantic relationship between the poet and his beloved.

Gözol Ceyran: It is about the poet's beloved. It shows his beloved is his religion, Faith and his second god. She is like a home or like blood inside the vessel of the poet. It depicts that the poet will die if he misses his beloved like a fish that dies on soil: 
Getmə mənim qəlbimdən,

Səndən sonra neynərəm,

Balıq kimi topraq üstə ölərəm.

Oh do not leave my heart,

I do not know what to do after you,

I will die after you like a fish out of water.

Ana Mən Qəribəm: It is about ana (mother) and bac1 (sister). The poet criticizes life for putting him into solitude. He addresses his mother/sister and complains about his homelessness/poorness. The poet uses some rare images to describe his complaints which are seen below:

Bizim dağda maral gəzər,

Dırnaxların daşlar əzər,

Mənə vırıb düşmən nəzər.

Qızıl gül kimi solmuşam,

Ana dünyadan doymuşam.

Deer is in our mountains,

Stones crush its nails,

My enemy has pointed to me,

I am wilting like a rose,

Oh mother, I am tired of life.

Ăgardı Saçım: The unfaithfulness of his beloved has been criticized by the poet since her unfaithfulness caused his hair go grey. The poet writes: Cavanam ömrüm keçdi ağardı açım/Bivafa yar əlindən mən hara qaçım, I am young, my life is passing and my hair goes grey/ to where can I go since my beloved is unfaithful. The poet believes that he is alone in this world. This song is a romantic song since it says '... Səni bir gün görməsəm inan ölərəm', in a case I do not see you (the singer's beloved), I will die.

Ana: It is about the poet's mother. It shows that his mother is like his eyesight. It talks about the lullaby that the singer's mother has played to him.

No Qaldı: This song is about the unfaithfulness of this world. It says that just God is eternal.

As far as what is mentioned, a brief summary of themes found in Neyniyim are shown in table 1.

Table 1. Neyniyim

\begin{tabular}{ll}
\hline$S n g$ & Theme \\
\hline Neynim & romance \\
Yadigar & nostalgic/loneliness \\
Həmdəm & romance \\
Gözəl Ceyran & romance \\
Ana mən qəribəm & mother/sister/criticism of life \\
Ağardı saçım & romance/ criticism of life \\
Ana & mother \\
Nə qaldı & criticism of life \\
\hline
\end{tabular}

Table 1 shows that romance, criticism of life and mother are the main themes of Jamshid Najafi's Neyniyim album.

\section{Gecələr}

This album has eight songs as Gecələr (nights), Qənari (canary), Bahar Gəldi (it's spring time), Qlzll Gül (rose), Bənəf̧̧ə or Banövşə (Viola), Atma məni (do not leave me alone), Balam (my beautiful sweetie) and Ana (Təbriz) (mother (Tabriz)). 
Gecələr: This song is the most well-known song of Jamshid Najafi. It is about the dark night that the singer is exhausted. This song shows the long nights that he cannot sleep. He says that my star (beloved) has been sulked and has been blown like wind and has terminated his life. The singer believes that the odor of morning is meaningless without his beloved. The complete verses with English translation can be found in the following:

\section{Gecələr}

Gəlmə qaranlıq gecələr,

Taqətim yoxdur gecələr,

Gözlərim töksə yaşını,

Dəryadan çoxdur gecələr,

Taqətim yoxdur gecələr.

Gecələr uzun gecələr səssiz,

Səhərin ətrin neynirəm sənsiz.

Ağlayır qəlbim gözlərim xəstə,

Yata bilmirəm gəl məni səslə.

Pəncərini bağladım,

Yuxu gələ gözümə,

Gördüm yuxuda bəxtim,

Ağlır yanan közümə.

Ulduzum küsüb gedib,

Yel kimi əsib gedib,

Ayındım bir vaxt gördüm,

Ömrümü kəsib gedib.

Do not come at dark nights,

I am exhausted at nights,

If my eyes pour,

Oh nights, their drops are greater than the sea.

I am exhausted at nights.

At nights, at long nights without any sound,

I do not want the smell of morning.

My heart is crying, my eyes are sick,

I closed the door,

(Since I wanted) Sleep creeps to my eyes,

I dreamed my chance,

Is crying for my burning eyes?

My star is sulked and has left me,

It has blown like wind,

I woke up and got,

It has cut my life.

An important point is that there is a harmony among the voice and music in this song. In this paper, just the poetry will be analyzed. Some beautiful images and collocations that are used in this poem are: Neynirom (which is translated as I do not want) is a word (and also is a sentence as it is seen in the translation given by the writers since Turkish is an agglutinative language) that has some implied meanings and senses in addition to its literal meaning that cannot be transferred by translating it into English. It signifies a kind of sulking that the poet has not 
mentioned directly. In other words, he does not want the smell of morning without his beloved when he recites Sahrin atrin neyniram on iz with a special stress on both neynirəm and $ә n i z$. When neyniramcollocates with sənsiz (without you), it transfers a feeling that the poet requests his beloved to come earlier. These implied meanings and senses which cannot be translated into English are hidden in Gecalor. Another important point about this poem is the crying of poet's chance to his burning eyes. This verse adds more beauty to the poem with its unique imaginative image. Another rare image seen in this poem is in Ulduzum kü üb gedib, Yel kimi a ib gedib/ My tar $i$ ulked and ha left me, It ha bl wn like the wind.

Qənari: This song is about a canary that has been raised by the singer and it has been flown away and his cage is empty now.

Bahar Gəldi: This song is about welcoming spring and also about singer's child.

Qızl gül: This song is a romantic piece of work that shows some beautiful images like:

Q1zıl gülümün rəngi niyə sarald,,

Cavan arzıları ürəyində qaldı,

Ağlayır güllər sənin halına,

Yanır bülbüllər bu əhvalına,

Ağlama sən ağlama ürəyimi dağlama, ...

Why color of my rose has changed,

Its young dreams remained in its heart,

The flowers are taking pity on you,

The clouds are feeling pity for you,

Stop crying, you stop crying, do not hurt my heart, ...

As far as the selected verses of this song are concerned, a romantic sense of poet is undeniable in this song.

\section{Bənəfşə (Bənövşə)}

The poet criticizes his beloved for being late and says:

Demişdin bir aya gəlləm,

Bir il oldu sən gəlmədin.

You promised me to come back in one month,

It is a year but you have not come yet.

This song is replete with romantic images like:

Nə bənəfşə nə qızıl gül sənin ətrini vermədi,

Səndən sonra aşiq quşlar bizim eyvana gəlmədi. ...

Sən qəlbimin Allahısan, ağlar gözüm pənahısan.

Gəl yetiş mənim dadıma, qəlbim yansa günahlısan.

Not viola nor rose smell like you,

The love birds did not come to our porch after you...

Your are the god of my heart, shelter of my crying eyes,

Come, help me, if I miss you, you are responsible.

Atma məni:This is a romantic song.

Gözəl Balam: This song is about singer's child who is in travel and he misses him/her. He remembers his child and his memories when he looks at roses.

Ana (Təbriz): This song is about mother and homeland. The poet talks about homesickness and his deep sorrow of separation from the Iranian city of Tabriz (his native soil). The song is about El-Gölü (also known as Şah-Gölü which is one of the beautiful parks with traditional architecture of Iranian Azerbaijan located in Tabriz) and lack of həmzaban (a native speaker). It says that my heart is beating for Tabriz. The song shows that Ana and Tabriz are equal. 
According to what is mentioned, relevant themes found in Gecalor can be seen in table 2.

Table 2. Gecələr

\begin{tabular}{ll}
\hline$S n g$ & Theme \\
\hline Gecələr & romance \\
Qənari & romance \\
Bahar gəldi & His child/welcoming spring \\
Gizıl gül & romance \\
Bənəf̧̧ə & romance \\
Atma məni & His child/romance \\
Gözəl balam & His child/romance \\
Ana (Təbriz) & mother/ homeland/ Tabriz/ El-Gölü \\
\hline
\end{tabular}

According to the themes reported in table 2, romance is the most frequent theme in Gecalar album of Jamshid Najafi. Also his child is the next frequent theme.

\section{Gəldi Baba}

This album has eight songs: Galdi Baba (daddy has come), Güldaran (flower picker), Ana (mother), Baliqlar (fish), Biganə (stranger), Səfay-i Bahar (beauty of spring), Məcnun (Majnun) and Mənim A $\breve{g} a m$ (my master).

Gəldi Baba: This song is one of the most well-known songs of Jamshid Najafi. He sings to his daughter. His love toward his daughter can be seen in this song. Goldi Baba and its translation can be seen in the following:

\section{Gəldi Baba}

Nazlı gizım ceyran balam,

Aç qapını gəldi Baba gəldi Baba.

Qollarını sal boynuma,

Yorğun canım sənə fəda,

Aç qapını gəldi Baba gəldi Baba.

Evimin 1 şı̆̆g çırağ

Qəlbimin yaprağı budağı sənsən,

Sən olmasan dünyanı mən neynirəm,

Könlümün ümudu dayağı sənsən.

Sənsən, sənsən dünyam,

Sənsən ömrüm röyam,

Ata Ana uşaqlara pənahdır,

Allah özü hamıya tekyegahdır.

Uşaq bir qunçadır Ana bağiban,

Ata bir zəhmətkeş mehrəban insane.

Oh my adorable daughter, my beautiful sweetie,

Open the door, daddy has come, daddy has come,

Put your arms around my neck,

Oh my tired soul is dedicated to you,

Open the door, daddy has come, daddy has come,

You are the torch and brightness of my house,

You are leaf and bough of heart,

If you are not (alive), I do not want life anymore,

You are the hope and pillar of my heart. 
You are, you are my world, life and dream.

Father and mother are shelter for their child,

God is shelter for all people,

Child is like a bud, mother is like a gardener,

Father is like a kind human.

\section{Güldərən}

This song is a romantic song.

\section{Ana}

This song is devoted to mother's status that occupies a holy position in all cultures including Azerbaijani culture.

\section{Balıqlar}

This song is a critical poem that complains about fishing and says:

Bu qədər səyyad toru atma dəryadə qalsın,

Rəva deyil balığın canını insan alsın.

Do not pull the fishnet through the sea,

Taking lives of fish by human is not fair.

\section{Biganə}

This song is about faithfulness of a devotee that will not quit his homeland as it can be seen in the following:

İgid oğlan elin atmaz dostunu namərdə satmaz,

Qurbət ölkə beheşt olsa vətən toprağına çatmaz.

A devotee does not leave his homeland, he is faithful to his friend,

He does not forget his homeland even if the foreign country is like heaven.

The significance of devotee can be seen in Azerbaijnai poems on the one hand and in Azerbaijani proverbs on the other hand as reported by Shahiditabar and Setayesh (2015).

\section{Səfay-i Bahar}

This song is welcoming spring.

Məcnun: This song is about singer's love that has no helper except God. He depicts himself as Majnoon. Majnoon is a romantic character extracted from LEYLI O MAJNUN. According to iranicaonline.org, LEYLI O MAJNUN is a romantic narrative poem of approximately 4,600 lines composed in 584/1188 by the famous poet Nezāmi of Ganja. It is the third of Nezāmi of Ganja five long narrative poems known collectively as the Kam $a$ (the Quintet).

Mənim Ağam: This song is one of the songs that shows the singer's (and poet's) dedication to Imam Reza (a.s.) as we can see:

... Ahunu balasına yetirən qərib ağa,

Dəxiləm dərgahinə gələ o əziz bala...

... I ask the Master who helped the deer to reach to its baby to help me find my baby ...

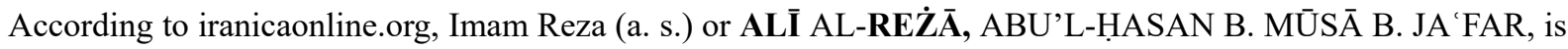
the eighth Imam of the Emāmī Shi ites. He was born and grew up in Medina. The year of his birth is variously given as 148/765, 151/768, and 153/770.

According to what is presented, summary of the themes found in Galdi Baba can be seen in table 3.

Table 3. Gldi baba

\begin{tabular}{ll}
\hline \multicolumn{1}{c}{$S n g$} & \multicolumn{1}{r}{ Theme } \\
\hline Gəldi baba & his child/romance \\
Güldərən & romance \\
Ana & mother \\
\hline
\end{tabular}




\begin{tabular}{ll}
\hline Balıqlar & criticism of fishing \\
Biganə & devotee \\
Səfay-i bahar & welcoming spring \\
Məcnun & romance \\
Mənim Ağam & religious person \\
\hline
\end{tabular}

As it is seen in table 3, romance and family (mother/child) are the most frequent themes found in Gəldi Baba.

\section{Axşamlar}

This album has eight songs as Gəlin Bacı (bride sister), Çağır Məni (call me), T yun Mubarək (happy wedding) Vay Qəlbim (oh my heart), Axşamlar (evenings), Gecalar (nights) Xalabanlar (pilots) and Şirin Va Fərhad (Shirin and Farhad).

\section{Gəlin Bacı}

This song is a romantic poem. It shows the cultural significance of sister's position in Turkish custom. It says that Sən bu evin çırağı an, inan qalbim on iz yatar, $Y$ u are the light $f$ thi $h u$ e, believe me, my heart will $t p$ $w$ rking if y u leave me al ne.

\section{Çă̆ır Məni}

This romantic song is about separation of the poet from his beloved as he writes:

$\mathrm{Bu}$ ayrılıq üzdü bizi,

Qəm sapına düzdü bizi, ...

... Aramıza söz atdılar,

Səni məni ağlatdılar.

This separation annoyed us,

It put us on melancholy string, ...

... They said something about us,

They made us cry.

\section{Toyun Mubarək}

As the name suggests in Azerbaijani, this work is a happy birthday song.

\section{Vay Qəlbim}

This romantic song is about separation of the poet from his beloved as he writes:

Bixəbər getdi o yar qurbətə yandırdı məni,

Bivəfa dünyada yarım kimə tapşırdı məni.

My beloved left me unannounced, she broke my heart,

To whom my beloved addressed me in this faithless world.

\section{Axşamlar}

This romantic song starts with a verse quoted from Aliagha Vahid (1895-1965), an Azerbaijani poet who honored Artist of the Azerbaijan SSR (1943) and reintroduced medieval ghazelstyle in Azerbaijani poetry in Baku as:

Düşəndə türre-i dilbər xəyala axşamlar,

Məhəbbət əhli düşər min məlalə axşamlar.

When the hair of beloved falls in dreams,

The lovers fall in thousands of boredoms in the eveningsVahid (2006).

\section{Gecələr}

This is another romantic song that its name echoes Najafi's most well-known song. This song is different from his other song with the same name. It starts with:

Yalvarıram səhərə açmaki yar gələcək,...

I ask the sun not to rise since the beloved is going to come, ... 


\section{Xələbanlar}

This is an epic piece of art dedicated to Iran's Army during the 8-years of imposed war between Iraq and Iran. This song was released in 1981. This song is bilingual (Farsi- Azerbaijani Turkish). The Azerbaijani Turkish part of the song is seen in thefollowing lines:

Vırışırlar ərtişimiz həryanda,

Göy üzündə dəryalarda dağlarda.

Həqq yolundan din yolundan dönməzlər,

Nəqədər qudrətləri var canlarda.

Xələbanlar xələbanlar yurdumuza iftixarsız.

Xələbanlar .....

Qnad aç qanad aç.

Ortişimiz var olsun, Allah sizə yar olsun.

Our army is fighting everywhere,

In the sky, in the sea and in the mountains.

They do not divert from the truth and the religious path,

To the best of their lives.

Oh pilots, your are the pride of our land.

Oh pilots, ....

Fly, Fly.

Long life with our army, Allah saves you.

\section{Şirin Va Forhad}

This song is a romantic song as its name suggests. This song is about Shirin and Farhad. Farhad is a romantic figure in Iran's legend and literature according to iranicaonline.org. Farhad is best known from the poetry of Neẓāmī Ganjavī as a rival with the Sasanian King Kosrow II Parvēz (r. 591-628) for the love of the beautiful Armenian princess Šìīin.

A brief summary of themes found in Axşamlar can be seen in table 4 .

Table 4. Axşamlar

\begin{tabular}{lll}
\hline & $S n g$ & \\
\hline Gəlin bacı & sister \\
Çağır məni & romance \\
Toyun mubarək & birthday \\
Vay qəlbim & romance \\
Axşamlar & romance \\
Gecələr & romance \\
Xələbanlar & Army (patriotism) \\
Şirin və Fərhad & romance \\
\hline
\end{tabular}

As it can be seen, romance is the most paramount theme found in this album.

\section{Discussion}

Regarding what is mentioned about Jamshid Najafi's songs, following themes with frequencies can be shown:

Table 5. Themes found in Jamshid Najafi's Works

\begin{tabular}{lll}
\hline & Theme & Frequency \\
\hline romance & 18 \\
mother & 4 \\
\hline
\end{tabular}




\begin{tabular}{ll}
\hline child & 4 \\
criticism of life and nostology & 4 \\
devotee, patriotism and homeland & 3 \\
spring & 2 \\
religious person & 1 \\
other & 4 \\
total & 39 \\
\hline
\end{tabular}

A brief glance at the themes unearthed shows that the first theme found in Najafi's songs is romance. It shows that Najafi is a romantic singer whose Azerbaijani Turkish songs are replete with romantic images and themes. The linguistic collocation of the poem has intensified its beauty. The next frequent theme found in Jamshid Najfi's work is mother that shows the holy position of mother in Azerbaijani culture. An important point is that when the song is about romance or even any other theme, mother is used by the poet to describe the themes as well. Mother is the next frequent theme found in Najafi's works. After mother, child is the next frequent theme in the studied corpus. It can be argued that family (mother, sister and child) has obtained 9 in Najafi's songs that shows his belief to the mentioned themes. Criticism of life and nostalgic themes are the next themes found in the studied corpus. Devotee, patriotism, homeland and religion are other most frequent themes in Jamshid Najafi's songs that show the roles these themes play in his life and ideology.

To sum up, following conclusion can be drawn using themes discussed: Jamshid Najafi is a romantic singer that the tinge of family (mother, sister and child) and its significant role in his life can be found in his songs. He is patriot and religious. His songs show some of Azerbaijani cultural values such as family, homeland and devotee.

\section{References}

Faghih, S. (2014). Echoes of Iranian Azerbaijani-Turkish Poetry: A Parallel Text in English and AzerbaijaniTurkish. Bridges Publishing.

Heyat, J. (1979). Azerbaijan adabiyat tarikhina bir bakhish (A view in Literature of Azerbaijan). Tehran. Varliq. In Turkic.

Heyat, J. (2001). Seyri da tarikh va lahjehaye Turki (A view in history of Turkish language and Accents). Tehran, Peykan Publication. In Farsi.

Heyat, J. (2006). VARLIQ-Quarterly Journal in Turkish and Farsi. Nom 141. In Turkic.

Mirəhməvov, Ә., \& Xanbabayeva, S. (2005). Azərbaycan Klassik Әdəbiyyatından Seçmələr. Üç Cilddə 1 Cild. VII-XII Osrlər Azərbaycan Şeiri. Bakı. Şərq-Qərb.

Mohammadzadeh, S. H. (2004). Dīwānu l-Lug̉at al-Turk. Tabriz. Akhtar Publications. Turkic and Farsi.

Mohammadzadeh, S. H. (2006). Bargozideye motune nazme Turki (az Mahmoode Kashqari ta Qaribiye Tabrizi (The Anthology of Turkic Poetry (From Mahmud al-Kashgari to Qribi of Tabriz).

Mohammadzadeh, S. H., \& Shirmohammadi (2009). Zurub amsale Turkiyya. (Turkish Proverbs). Tehran. Takderakht.

Mozaheb, M. A., \& Shahiditabar, M. (2015). A Content-Based Analysis of Fuzuli's Azebaijani Turkish Poems Tested against Qur'anic Themes. IJASOS- Internati nal E-J urnal $f$ Advance in $S$ cial Science , I(2), August 2015. https://doi.org/10.18769/ijasos.74447

Mozaheb, M. A., Shahiditabar, M., Monfared, A., \& Mirzapour, F. (2016). A Content-based Analysis of Shahriar's Azerbaijani Turkish Poem Getmə Tərsa Balası (A Christian Child) in Terms of Religious Images and Interpretations Mohammad Amin. Internati nal J urnal f Applied Lingui tic \& Engli h Literature, 5(2), March 2016.

Qəhrəmanov, C. (2005). Azərbaycan klassik ədəbiyyatından seçmələr. Bakı: Şərq-qərb.

Rüstəmova, A. (2002). Seyre Qazal der adabiyat Azerbaijan (A survey of ghazal in Azerbaijani literature). Translator; Nadali, Payam. Ardabil: Sheikh Safi-ad-din Publication. In Farsi.

Shahiditabar, M., \& Setayesh, K. (2015). A Content-Based Analysis of Humanity in Azerbaijani Proverbs. Internati nal $J$ urnal $f$ Inn vati $n$ and Re earch in Educati nal Science, 2(5).

Shahiditabar, M., Mozaheb, M. A., \& Monfared, A. (2015). Islamic Themes Found through Content-based Analysis of Shahriar's Azerbaijani Turkish Poems. The Engli h Literature J urnal, 6(2015), 519-521. 
Vahid, A. (2006). Kulliyat-i Vahid qəzəlləri və Ayrı Әsərlərı. Təbriz. Fəxr Azər.

Vazife, V. (2004). Divane Nizamiye Ganjavi Turkja yeni tapilan (Divan of Nizami Ganjavi: A newly reported Turkish collection). Andisheye Now. In Turkic.

Vazife, V. (2013). Ganjadan Galiram. Ashare Turkiye Nezamiye Ganjavi va Nezamiye Qaramanli. (I'm coming from Ganjah: Turkish poems of Nizami Ganjavi and Nizami Qunavi). Pardise Danesh. In Turkic.

\section{Websites}

http://www.imamreza.net/eng/imamreza.

http://www.iranicaonline.org/articles/ali-al-reza

http://www.iranicaonline.org/articles/farhad

http://www.iranicaonline.org/articles/leyli-o-majnun-narrative-poem

\section{Copyrights}

Copyright for this article is retained by the author(s), with first publication rights granted to the journal.

This is an open-access article distributed under the terms and conditions of the Creative Commons Attribution license (http://creativecommons.org/licenses/by/4.0/). 